\title{
Antioxidant activity and protective effect of Clitoria ternatea flower extract on testicular damage induced by ketoconazole in rats*
}

\author{
Sitthichai IAMSAARD ${ }^{\dagger 1,2}$, Jaturon BURAWAT ${ }^{1,2}$, Pipatpong KANLA ${ }^{1}$, Supatcharee ARUN ${ }^{1,2}$, \\ Wannisa SUKHORUM ${ }^{1,2}$, Bungorn SRIPANIDKULCHAI ${ }^{2}$, Nongnut UABUNDIT ${ }^{1}$, \\ Jintanaporn WATTATHORN ${ }^{1}$, Wiphawi HIPKAEO ${ }^{1}$, Duriya FONGMOON ${ }^{3}$, Hisatake KONDO ${ }^{1}$ \\ $\left({ }^{1}\right.$ Department of Anatomy and Integrative Complementary Alternative Medicine Research and Development Group, \\ Faculty of Medicine, Khon Kaen University, Khon Kaen 40002, Thailand) \\ $\left({ }^{2}\right.$ Center for Research and Development of Herbal Health Products, Faculty of Pharmaceutical Sciences, \\ Khon Kaen University, Khon Kaen 40002, Thailand) \\ $\left({ }^{3}\right.$ Department of Medical Services, Lampang Cancer Hospital, Ministry of Public health, Lampang 52000, Thailand) \\ †E-mail: iamsaard_sitt@yahoo.com
}

Received Nov. 23, 2013; Revision accepted Mar. 17, 2014; Crosschecked May 25, 2014

\begin{abstract}
Background: Ketoconazole (KET), an antifungal drug, has adverse effects on the male reproductive system. Pre-treatments with antioxidant plant against testicular damage induced by KET are required. The flowers of Clitoria ternatea (CT) are proven to have hepatoprotective potential. However, the protective effect on KET-induced testicular damage has not been reported. Objective: To investigate the protective effect of CT flower extracts with antioxidant activity on male reproductive parameters including sperm concentration, serum testosterone level, histopathology of the testis, and testicular tyrosine phosphorylation levels in rats induced with KET. Methods: The antioxidant activity of CT flower extracts was determined using 2,2-diphenyl-1-picrylhydrazyl (DPPH) and ferric reducing antioxidant power (FRAP) assays. Male rats were treated with CT flower extracts $(10,50$, or $100 \mathrm{mg} / \mathrm{kg} \mathrm{BW})$ or distilled water via a gastric tube for $28 \mathrm{~d}$ (preventive period: Days 1-21) and induced by KET (100 mg/kg BW) via intraperitoneal injection for $7 \mathrm{~d}$ (induction period: Days 22-28). After the experiment, all animals were examined for the weights of the testis, epididymis plus vas deferens and seminal vesicle, serum testosterone levels, sperm concentration, histological structures and diameter of testis, and testicular tyrosine phosphorylation levels by immunoblotting. Results: The CT flower extracts had capabilities for DPPH scavenging and high reducing power. At $100 \mathrm{mg} / \mathrm{kg} \mathrm{BW}$, the extract had no toxic effects on the male reproductive system. Significantly, in CT+KET groups, CT flower extracts (50 and $100 \mathrm{mg} / \mathrm{kg} \mathrm{BW}$ ) alleviated the reduction of reproductive organ weight parameters, testosterone levels, and sperm concentration. In addition, CT flower extracts gave protection from testicular damage in KET-induced rats. Moreover, in the CT100+KET group, CT flower extracts significantly enhanced the expression of a testicular 50-kDa tyrosine phosphorylated protein compared with that of other groups. Conclusions: C. ternatea flower extracts possessing antioxidant activity are not harmful to the male reproductive system and can protect against testicular damage in KET-induced rats.
\end{abstract}

Key words: Clitoria ternatea (CT) flower extracts, Antioxidant activity, Ketoconazole (KET), Testicular damage, Testicular tyrosine phosphorylation doi:10.1631/jzus.B1300299

Document code: A

CLC number: R931

\section{Introduction}

\footnotetext{
* Project supported by the Faculty of Medicine, Khon Kaen University (No. I 55222), Thailand

(c) Zhejiang University and Springer-Verlag Berlin Heidelberg 2014
}

Ketoconazole (KET) is an antifungal drug commonly used for treatment of advanced prostate cancer (Rodriguez and Acosta, 1995; Kinobe et al., 
2006). However, adverse effects of KET on the male reproductive system in both humans and animals have been documented. Significantly, KET was reported to decrease the weight of male reproductive organs, especially the testes, and to reduce epididymal sperm concentration and serum testosterone levels (Pon, 1987; Adams et al., 1998; Marwaha and Maheshwari, 1999; Amin, 2008). Moreover, Amin (2008) has also reported damage to rat testes induced by KET intraperitoneal (i.p.) injection (i.e., atrophy of seminiferous tubules, degeneration of Sertoli and germ cells, and sloughing of germ cells). Interestingly, such pathological changes in KET-treated rat testes could be prevented by pretreatment and co-administration with an antioxidant plant extract (Amin, 2008). Recently, there have been studies searching for non-toxic medicinal plants with antioxidant activity for use in the prevention of testicular damage. Our recent study suggested that an increase in phosphorylation levels of testicular proteins caused by administration of antioxidant plant extracts could be ascribed to testosterone production and spermatogenesis (Iamsaard et al., 2013).

Clitoria ternatea (CT) Linn. (called "Unchan" in Thailand) is a climbing vine bearing purple or white flowers. Every part of the CT vine has been systematically analyzed and revealed to have various medicinal properties (Patil and Patil, 2011). In Thailand, the purple flowers are used for many medical purposes and it is believed that they have antoxidant capacity. Mukherjee et al. (2008) reviewed the use of $\mathrm{CT}$ in Ayurvedic medicine and found that CT has been commonly used in anti-stress, anti-depressant, anti-microbial, and anti-inflammatory treatments. Moreover, CT has been shown to have significant hepatoprotective effects on drug-induced liver damage (Nithianantham et al., 2011). To our knowledge, the potential protective effects of CT flower extracts against KET-induced testicular damage in rats have not been reported. Therefore, the aim of this study was to evaluate the antioxidant activities and potential protective effects of aqueous CT flower extracts on KET-induced testicular damage in rats.

\section{Materials and methods}

\subsection{Chemicals and reagents}

KET (200 mg/tablet; KETOHIM) was pur- chased from a local drug store. Folin-Ciocalteau's reagent, 2,2-diphenyl-1-picrylhydrazyl (DPPH), acetate buffer, 2,4,6-tripyridyl-s-triazine (TPTZ), and ferric chloride $\left(\mathrm{FeCl}_{3}\right)$ were purchased from SigmaAldrich Co., Ltd. (Thailand). Ascorbic acid and other chemicals were of analytical grade.

\subsection{Plant collection and extraction}

The fresh purple CT flowers were collected from Khon Kaen Province, Thailand, in June to July 2012. Species identification was confirmed by Prof. Pranom CHANTARANOTHAI, a plant taxonomist, from Khon Kaen University (KKU), Thailand. Voucher specimens of CT were kept in the KKU Herbarium (No. Jaturon Burawat 01 [KKU]). In the extraction process, the CT flowers were washed with distilled water and air dried for two days. The dried flowers were crushed with a hammer mill crusher (AEG IP54 Lbi 07, Germany) for $30 \mathrm{~min}$. Then, the crushed sample $(3 \mathrm{~kg})$ was extracted with $10 \mathrm{~L}$ of distilled water and boiled at $95-100^{\circ} \mathrm{C}$ for $30 \mathrm{~min}$. The soluble extract was filtered through nylon. The filtrate was dried using lyophylization. The extraction yield of aqueous extract from CT flowers was $3.97 \mathrm{~g}$.

\subsection{DPPH radical scavenging assay and deter- mination of half maximum inhibition concentra- tion $\left(\mathrm{IC}_{50}\right)$}

The radical scavenging activity of the $\mathrm{CT}$ aqueous extract was determined using DPPH assay (BrandWilliams et al., 1995). Briefly, five concentrations of the CT flower extracts were prepared from a concentrated extract stock solution to provide a concentration plot. Each concentration of CT flower extracts $(2 \mathrm{ml})$ was mixed with $2 \mathrm{ml}$ DPPH in $0.004 \%(\mathrm{v} / \mathrm{v})$ methanol and incubated at room temperature in dark for $30 \mathrm{~min}$. The absorbance was recorded at $517 \mathrm{~nm}$ using an ultraviolet-visible (UV/VIS) spectrophotometer (Jasco V530, Japan). Ascorbic acid (1, 3, 5, 8, and $14 \mu \mathrm{g} / \mathrm{ml})$ was used as the positive standard. All samples were measured in triplicate. The scavenging activity of the CT flower extracts or standard was calculated as the percent inhibition of DPPH radical scavenging activity using a standard formula as (absorbance of control-absorbance of sample) $\times 100 \%$ / absorbance of control. Data were expressed as the $\mathrm{IC}_{50}$ calculated from the point of $50 \%$ inhibition against the concentration $(\mu \mathrm{g} / \mathrm{ml})$ plot. 


\subsection{Ferric reducing antioxidant power (FRAP) assay}

Reducing power capacity was determined using the FRAP assay (Benzie and Strain, 1996). Briefly, $0.1 \mathrm{ml}$ of five different concentrations of CT flower extracts were mixed with $3 \mathrm{ml}$ of FRAP reagent (containing $300 \mathrm{mmol} / \mathrm{L}$ acetate buffer, $10 \mathrm{mmol} / \mathrm{L}$ TPTZ, and $20 \mathrm{mmol} / \mathrm{L} \mathrm{FeCl}_{3}$, in a volume ratio of 10:1:1). The CT mixture was incubated in dark for $20 \mathrm{~min}$ and the absorbance was recorded at $593 \mathrm{~nm}$ using a UV/VIS spectrophotometer. For standard preparation, six concentrations of ascorbic acid (5.76, $9.60,17.28,24.00,32.00$, and $48.00 \mu \mathrm{g} / \mathrm{ml}$ ) were plotted to determine its reducing power.

\subsection{Animals and treatment regime}

Male Sprague-Dawley rats (180-200 g) were purchased from the National Laboratory Animal Center, Salaya, Nakhon Pathom, Thailand. The study was approved by the Animal Ethics Committee of KKU, based on the Ethics of Animal Experimentation of the National Research Council of Thailand (ref. No. $0514.1 .12 .2 / 93)$. Thirty-six rats were divided into six groups and each group $(n=6)$ was treated as shown in Table 1.

\subsection{Histopathological examination of the testes}

On the day after termination of the CT-KET co-administration, all rats were euthanized by cervical dislocation and sacrificed to collect the male reproductive organs (i.e., testis, epididymis plus vas deferens, and seminal vesicle). These organs were subsequently removed of fats and weighed. To examine the testicular damage, testes were fixed in $10 \%(\mathrm{v} / \mathrm{v})$ formalin in phosphate buffered saline (PBS)
(pH 7.4), embedded in paraffin, sectioned at 4-6 $\mu \mathrm{m}$ thickness, and stained with hematoxylin-eosin (Iamsaard et al., 2013). All photographs were captured by a Nikon light ECLIPSE E200 microscope equipped with a DXM1200 digital camera. ImageJ was used to measure and calculate approximate average diameters of seminiferous tubules in four different axes (50 tubules per animal).

\subsection{Plasma testosterone assay}

At the end of the experiment, all animals were sacrificed to expose the left ventricle of the heart. Blood was collected by puncture of the left ventricular chamber using $1 \mathrm{ml}$ of heparin to prevent blood clotting. The blood was centrifuged at $5000 \mathrm{r} / \mathrm{min}$ at $4{ }^{\circ} \mathrm{C}$ for $10 \mathrm{~min}$ to separate the plasma serum from blood cells. The plasma testosterone concentration was assayed by enzymatic immunoassay at the Radiology Unit, Srinagarind Hospital, Faculty of Medicine, KKU, Thailand.

\subsection{Epididymal sperm concentration}

Mature sperm were collected from the left epididymis and vas deferens. Epididymal sperm fluid was dipped and re-suspended in $1 \mathrm{ml} \operatorname{PBS}\left(37^{\circ} \mathrm{C}\right.$, $\mathrm{pH} 7.4$ ) and centrifuged $\left(500 \mathrm{~g}, 37^{\circ} \mathrm{C}, 5 \mathrm{~min}\right)$ to wash and separate the mature sperm pellet from its fluid. To analyze the epididymal sperm concentration, the

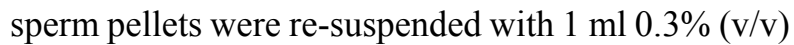
bovine serum albumin (BSA)-KSOM (potassiumenriched simplex optimized medium; EmbryoMax KSOM Powdered Mouse Embryo Culture Medium; Millipore catalogue No. R-MR-020P-5D). In triplicate preparations, the sperm solutions (1:20 dilution) were used to count mature sperm using a Neubauer counting chamber and to calculate their concentration (Iamsaard et al., 2013).

Table 1 Treatment on each group of rats

\begin{tabular}{lll}
\hline \multirow{2}{*}{ Group } & \multicolumn{2}{c}{ Treatment } \\
\cline { 2 - 3 } & \multicolumn{1}{c}{ Days 1-28 (via a gastric tube) } & Days 22-28 (intraperitoneal injection) \\
\hline Negative control & Distilled water, $1 \mathrm{ml}$ & Saline, $0.5 \mathrm{ml}$ \\
KET (positive control) & Distilled water, $1 \mathrm{ml}$ & KET $(100 \mathrm{mg} / \mathrm{kg} \mathrm{BW}), 0.5 \mathrm{ml}$ \\
CT100 & CT flower extracts $(100 \mathrm{mg} / \mathrm{kg} \mathrm{BW}), 1 \mathrm{ml}$ & Saline, $0.5 \mathrm{ml}$ \\
CT10+KET & CT flower extracts $(10 \mathrm{mg} / \mathrm{kg} \mathrm{BW}), 1 \mathrm{ml}$ & KET $(100 \mathrm{mg} / \mathrm{kg} \mathrm{BW}), 0.5 \mathrm{ml}$ \\
CT50+KET & CT flower extracts $(50 \mathrm{mg} / \mathrm{kg} \mathrm{BW}), 1 \mathrm{ml}$ & KET $(100 \mathrm{mg} / \mathrm{kg} \mathrm{BW}), 0.5 \mathrm{ml}$ \\
CT100+KET & CT flower extracts $(100 \mathrm{mg} / \mathrm{kg} \mathrm{BW}), 1 \mathrm{ml}$ & KET $(100 \mathrm{mg} / \mathrm{kg} \mathrm{BW}), 0.5 \mathrm{ml}$ \\
\hline
\end{tabular}

BW: body weight; KET: ketoconazole (saline-dissolved). The KET group (positive control) is designed based on Amin (2008). Days 1-21 are the preventive period and Days $22-28$ are the induction period 


\subsection{Western blot analysis for testicular tyrosine protein phosphorylation}

As described by Iamsaard et al. (2013), briefly, the left testis was homogenized with RIPA buffer (Cell Signaling Technology, Inc., USA) containing a cocktail of protease inhibitors. The testicular homogenate was then centrifuged at $12000 \mathrm{r} / \mathrm{mim}$ for $10 \mathrm{~min}$ to collect testicular lysate. The total protein concentration of the lysate was measured using a NanoDrop ND-1000 Spectrophotometer (NanoDrop Technologies, Inc., USA). Total proteins (60 $\mu \mathrm{g})$ collected from triplicate samples were separated by $10 \%(0.1 \mathrm{~g} / \mathrm{ml})$ sodium dodecyl sulfate polyacrylamide gel electrophoresis (SDS-PAGE) and blotted onto nitrocellulose membranes to detect the intensity of tyrosine phosphorylation using the 4G10 primary antibody (1:3000; Millipore Co., USA). For standard samples, BSA (AMRESCO ${ }^{\circledR}$, USA) was used as the negative control and epidermal growth factors (EGFs) (Millipore Co., USA) as the positive control. In the detection of phosphotyrosine proteins, the enhanced chemiluminescence (ECL) substrate was applied before visualization under gel doct 4 (ImageQuant 400 , GH Healthcare, USA). To quantify the levels of phosphorylation, the ImageJ program was used to analyze the relative intensity of phosphorylated protein bands among groups.

\subsection{Statistical analysis}

One-way analysis of variance (ANOVA) and $t$-test were used to examine the significance of differences among sets of data, and between pairs of data points using Sigma Stat program (Version 3.1.1). All quantitative results were expressed as mean \pm standard deviation (SD).

\section{Results}

\subsection{Antioxidant activity of CT flower extracts}

In the DPPH scavenging assay, the results showed that CT flower extracts possessed a concentration-response relationship in DPPH scavenging activity, using ascorbic acid as a positive control. Compared with the $\mathrm{IC}_{50}$ of ascorbic acid $[(5.34 \pm 0.09) \mu \mathrm{g} / \mathrm{ml}]$, the $\mathrm{IC}_{50}$ of CT was $(84.15 \pm$ $1.50) \mu \mathrm{g} / \mathrm{ml} \quad\left(y=0.0686 x+45.017, R^{2}=0.98\right)$. For the FRAP assay calibrated with standard ascorbic acid $\left(y=0.007 x+0.3769, R^{2}=0.9802\right)$, the reducing power of the CT flower extracts was $(0.33 \pm 0.01) \mathrm{mmol} / \mathrm{mg}$ ascorbic equivalent. These results demonstrate that the CT flower extracts used for preventive experiments in this study possessed antioxidant capacity.

\subsection{Weights of male reproductive organs}

After treatment for 28 consecutive days, the body weights of control and experimental groups were not different $(P>0.05)$. In contrast, all reproductive organs in KET-treated rats weighed significantly less than those of the controls $(P<0.05$; Table 2). We found that the CT flower extracts did not affect the weights of reproductive organs. In addition, all doses of CT flower extracts could prevent the weight loss of the testis in rats induced with KET (Table 2). Moreover, 50 and $100 \mathrm{mg} / \mathrm{kg}$ BW CT flower extracts significantly improved the weights of the epididymis plus vas deferens in KET-induced rats $(P<0.05)$. Only $100 \mathrm{mg} / \mathrm{kg}$ BW CT flower extracts prevented the weight loss of the seminal vesicle in the KET group $(P<0.05)$.

Table 2 Values of analyzed parameters on the reproductive system of control and experimental rats

\begin{tabular}{|c|c|c|c|c|c|c|}
\hline \multirow[b]{2}{*}{ Group } & \multicolumn{3}{|c|}{ Weight (g) } & \multirow{2}{*}{$\begin{array}{l}\text { Testicular } \\
\text { diameter } \\
(\mu \mathrm{m})\end{array}$} & \multirow{2}{*}{$\begin{array}{c}\text { Serum } \\
\text { testosterone } \\
\text { level }(\mathrm{ng} / \mathrm{ml})\end{array}$} & \multirow{2}{*}{$\begin{array}{c}\text { Sperm } \\
\text { concentration } \\
\left(\times 10^{6} \text { cells } / \mathrm{ml}\right)\end{array}$} \\
\hline & Testis & $\begin{array}{l}\text { Epididymis plus } \\
\text { vas deferens }\end{array}$ & $\begin{array}{l}\text { Seminal } \\
\text { vesicle }\end{array}$ & & & \\
\hline Control & $3.77 \pm 0.19$ & $0.66 \pm 0.04$ & $1.24 \pm 0.14$ & $304.00 \pm 7.30$ & $1.58 \pm 0.10$ & $33.46 \pm 4.30$ \\
\hline KET & $3.19 \pm 0.30^{*}$ & $0.53 \pm 0.06^{*}$ & $0.85 \pm 0.14^{*}$ & $265.25 \pm 1.77^{*}$ & $0.99 \pm 0.16^{*}$ & $20.67 \pm 2.01^{*}$ \\
\hline CT100 & $3.69 \pm 0.11$ & $0.63 \pm 0.04$ & $1.17 \pm 0.19$ & $291.50 \pm 2.44$ & $1.54 \pm 0.23$ & $28.67 \pm 3.84$ \\
\hline CT10+KET & $3.75 \pm 0.08$ & $0.56 \pm 0.12^{*}$ & $0.86 \pm 0.23^{*}$ & $269.50 \pm 7.97^{*}$ & $1.47 \pm 0.25$ & $21.17 \pm 2.70^{*}$ \\
\hline CT50+KET & $3.76 \pm 0.02$ & $0.63 \pm 0.06$ & $0.91 \pm 0.19^{*}$ & $300.75 \pm 6.26$ & $1.73 \pm 0.16$ & $31.00 \pm 3.45$ \\
\hline CT100+KET & $3.70 \pm 0.23$ & $0.65 \pm 0.06$ & $1.10 \pm 0.15$ & $303.25 \pm 5.78$ & $1.41 \pm 0.23$ & $29.46 \pm 4.07$ \\
\hline
\end{tabular}

\footnotetext{
${ }^{*}$ Significant differences $(P<0.05)$ as compared with the control group. Data are expressed as mean \pm SD $(n=6)$
} 


\subsection{Protective effects of CT flower extracts on KET-induced testicular damage}

The effects of CT flower extracts on testicular damage were examined by observing histopathological structures (Fig. 1). The result showed shrunken seminiferous tubules in the KET group compared with the controls (Figs. 1a and 1b). This finding was corroborated by their diameters (Table 2). In the KET group, the seminiferous tubules had very minor pathological effects (in fewer than $10 \%$ of tubules) including sloughing of germ cells, early cell

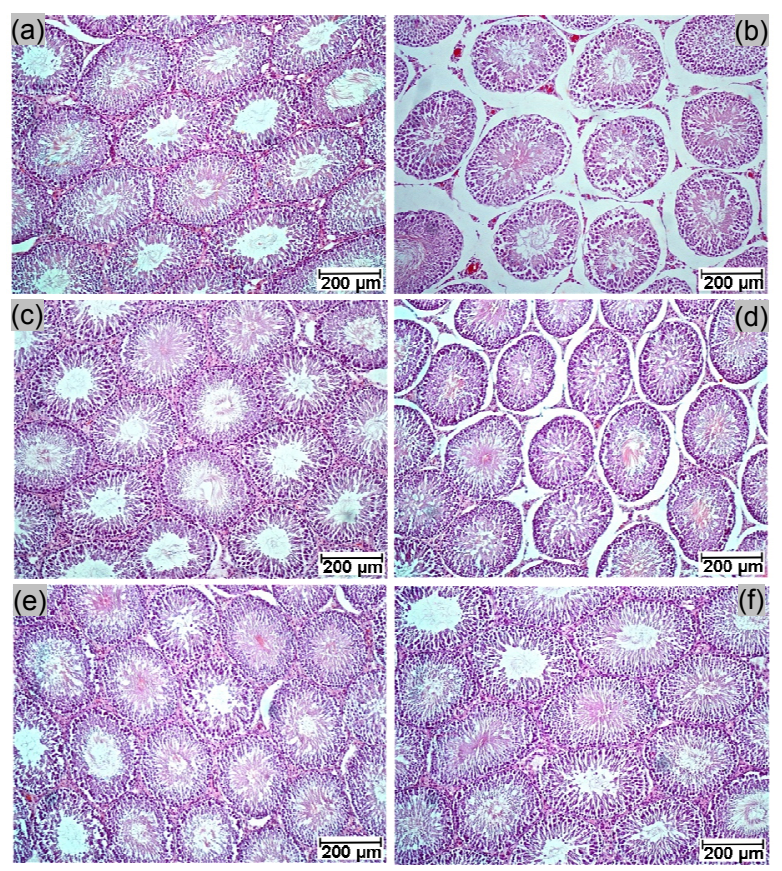

Fig. 1 Photographs showing rat testicular histology $(H \& E)$ from a representative section

(a) Control; (b) KET; (c) CT100; (d) CT10+KET; (e) CT50+ KET; (f) CT100+KET degeneration with giant cells, and late cell degeneration (Fig. 2). Some shrunken tubules with significantly reduced diameters (Table 2) and other abnormal seminiferous tubules could be found in the CT10+KET group (Fig. 1d). However, no histopathology or reduction in seminiferous tubule diameter was observed only in rats of the CT100, CT50+KET, and CT100+KET groups (Table 2; Figs. 1c, 1e, and 1f).

\subsection{Effects of CT flower extracts on serum testos- terone levels and epididymal sperm concentrations}

Table 2 shows that only the KET and CT10+KET groups had a significant decrease in serum testosterone levels compared with the controls. In contrast, $100 \mathrm{mg} / \mathrm{kg}$ BW CT flower extracts did not affect such levels, whereas 50 and $100 \mathrm{mg} / \mathrm{kg}$ BW CT flower extracts increased the testosterone hormone in KETinduced rats (Table 2). Similarly, not only the CT group but also the CT50+KET and CT100+KET groups showed no differences in epididymal sperm concentration compared with the controls (Table 2).

\subsection{Effects of CT flower extracts on testicular tyrosine protein phosphorylation}

Following immuno-Western blotting, four major phosphorylated proteins $(50,55,60$, and $65 \mathrm{kDa})$ of rat testicular lysate were clearly detected in both control and experimental groups. For densitometry analyses, we found that the relative intensity of the 55 , 60 , and $65 \mathrm{kDa}$ phosphorylated proteins was not significantly different (data not shown). Interestingly, a testicular $50-\mathrm{kDa}$ phosphorylated protein was especially intense in the CT100+KET group compared with other groups (Fig. 3).

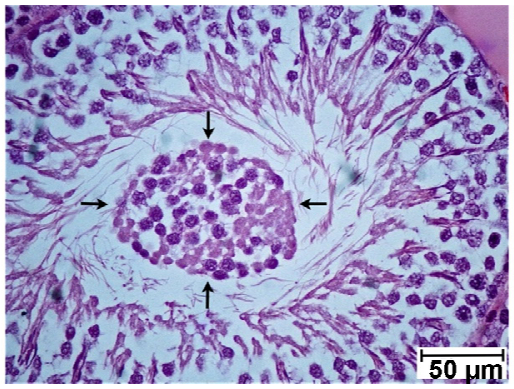

(a)

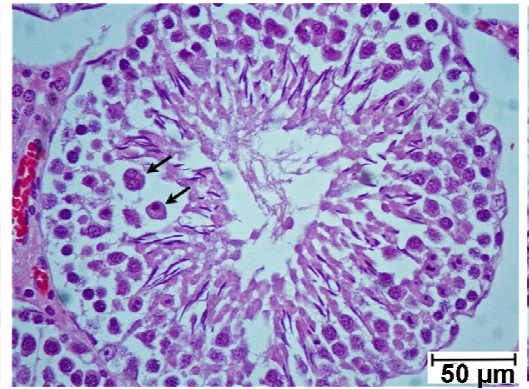

(b)

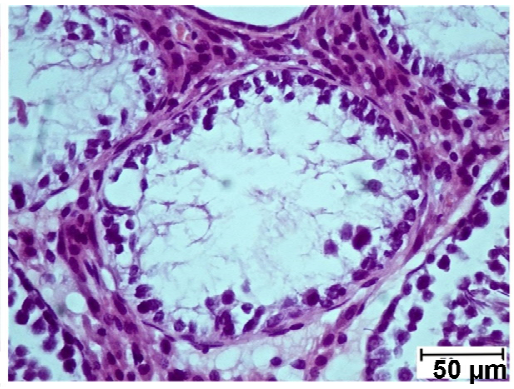

(c)

Fig. 2 Photographs showing histopathogy (H\&E) of seminiferous tubules observed in KET-induced rats from representative sections

(a) Sloughing of germ cells (arrows); (b) Early cell degeneration with giant cell (arrows); (c) Late cell degeneration 


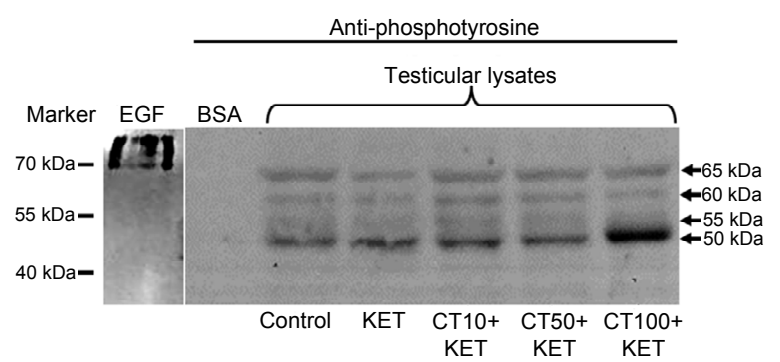

(a)

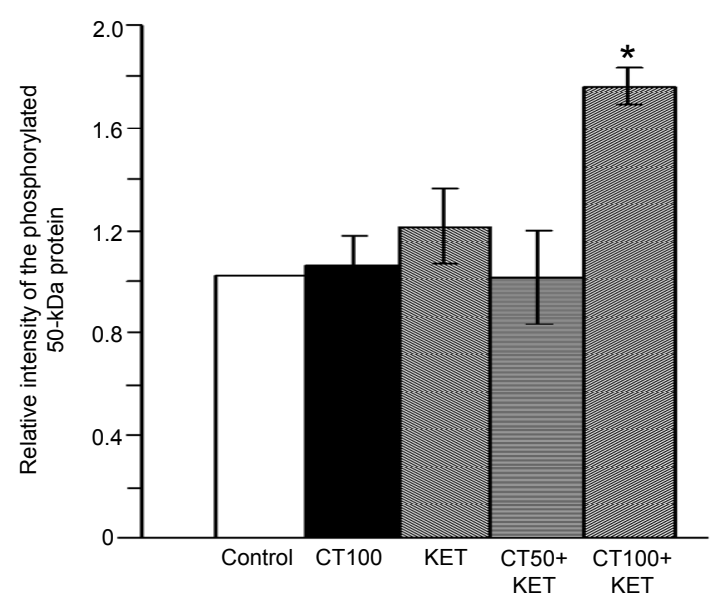

(b)

Fig. 3 Immuno-Western blot analysis for tyrosine protein phosphorylation levels in testicular lysates (a) and relative intensity of the phosphorylated 50-kDa protein of testicular lysate (b)

In (a), $60 \mu \mathrm{g}$ protein is for each lane of control, KET, and $\mathrm{CT}+\mathrm{KET}$ groups. Bovine serum albumin (BSA) and epidermal growth factor (EGF)-like growth factor were used as negative and positive controls for phosphotyrosine antibody, respectively. In (b), data are expressed as mean $\pm \mathrm{SD}(n=3)$. ${ }^{*} P<0.05$ vs. control

\section{Discussion}

The results in Table 2 suggest that high concentrations of CT flower extracts $(100 \mathrm{mg} / \mathrm{kg} \mathrm{BW})$ were not harmful to male reproductive parameters. By FRAP assay, the antioxidant activity of the CT aqueous extract in this study was comparable to the ferric reducing power of ascorbic acid. In addition, a group of polyacylated anthocyanins in this blue flower is already identified and crystallized (Honda and Saito, 2002; Hiromoto et al., 2013). Consistent with previous reports (Adams et al., 1998; Amin, 2008), in the present study, KET affected reproductive organ weight, sperm concentration, and serum testosterone levels (Table 2). Moreover, CT flower extracts have been shown to exhibit high cytotoxic activity against the breast cancer cells (Akter et al., 2014). The non-toxicity of the CT flower extracts and testicular toxicity of KET induction were further confirmed by histological observations in the testis tissues (Figs. 1b and 2). However, the testicular pathology observed in Fig. 2, which was similar to that described by Amin (2008), was not quantified among groups because it was found in less than $10 \%$ of rats in the KET group and was rarely found in the low-dose group of the CT flower extracts. It seemed that testicular damage in our study was less severe than that in the previous study (Amin, 2008). This may caused by that KET in our study was prepared from a tablet, while KET (Nizoral) in Amin (2008) was from a stock solution. In CT50+KET and CT100+KET groups, the pre-treatment of CT followed by co-administration with CT and KET significantly maintained male reproductive organ weights, except for that of the seminal vesicle in the CT50+KET group (Table 2). Similarly, CT + KET rats retained normal serum testosterone levels, sperm concentration, seminiferous tubule diameters, and testicular architecture compared with the control group (Table 2; Fig. 1). These results clearly demonstrate a potential protective effect of CT flower extracts on testicular damage of rats induced by KET.

It has been shown that KET can cause hepatotoxicity and testicular toxicity which was revealed by histopathology and biochemistry results (Amin and Hamza, 2005; Amin, 2008). In rats, KET-induced testicular damage was demonstrated to be associated with alterations to testicular levels of malondialdehyde, glutathaione, catalase, and superoxide dismutase (Amin, 2008). In addition, this oxidative stress damage and antioxidant depletion in rat testis were shown to be remarkably protected by an antioxidant plant extract (Amin, 2008). Unfortunately, the extract in the present study has not shown such associations, but it was assumed to have the same action since it had high antioxidant activity. Increasingly, posttranslational phosphorylated tyrosine proteins are being shown to be involved in many biological processes including sperm production, capacitation, and acrosome reaction (Morales et al., 2007; Bailey, 2010; Fardilha et al., 2011; Yamashita et al., 2011). For the first time, we attempted to explain changes in 
testicular tyrosine protein phosphorylation levels between control and experimental groups induced with KET (Fig. 3). However, the four major tyrosinephosphorylated proteins present in the testicular lysate were not different from those of the control (Fig. 3), suggesting that testicular damage by KET induction was not associated with tyrosine phosphorylated proteins. In this study, the blot was cropped to demonstrate only testicular proteins against tyrosine phosphorylated antibody. Interestingly, a $50-\mathrm{kDa}$ tyrosine phosphorylated protein showed high expression only in the CT100+KET group (Figs. 3a and 3b), but not in the CT100 or lower-dose CT+KET groups. In contrast, the relative intensities of the other three tyrosine phosphorylated proteins $(65,60$, and $55 \mathrm{kDa}$; Table 2) were not significantly different from each other or the control (data not shown). The possible role of over-expression of a 50-kDa tyrosine phosphorylated protein in KET-induced testicular damage in rats reduced by CT flower extracts is still unclear. Similar to a previous report, this could be partially explained if this $50-\mathrm{kDa}$ protein is responsible for testosterone production (Iamsaard et al., 2013).

In conclusion, CT extract has antioxidant activity, which is harmless and can reduce KET-induced testicular damage in rats.

\section{Compliance with ethics guidelines}

Sitthichai IAMSAARD, Jaturon BURAWAT, Pipatpong KANLA, Supatcharee ARUN, Wannisa SUKHORUM, Bungorn SRIPANIDKULCHAI, Nongnut UABUNDIT, Jintanaporn WATTATHORN, Wiphawi HIPKAEO, Duriya FONGMOON, and Hisatake KONDO declare that they have no conflict of interest.

All institutional and national guidelines for the care and use of laboratory animals were followed.

\section{References}

Adams, M.L., Meyer, E.R., Cicero, T.J., 1998. Imidazoles suppress rat testosterone secretion and testicular interstitial fluid formation in vivo. Biol. Reprod., 59(2):248-254. [doi:10.1095/biolreprod59.2.248]

Akter, R., Uddin, S.J., Grice, I.D., et al., 2014. Cytotoxic activity screening of Bangladeshi medicinal plant extracts. J. Nat. Med., 68(1):246-252. [doi:10.1007/s11418-0130789-5]

Amin, A., 2008. Ketoconazole-induced testicular damage in rats reduced by Gentiana extract. Exp. Toxicol. Pathol., 59(6):377-384. [doi:10.1016/j.etp.2007.10.008]

Amin, A., Hamza, A.A., 2005. Oxidative stress mediates drug-induced hepatotoxicity in rats: a possible role of
DNA fragmentation. Toxicology, 208(3):367-375. [doi:10. 1016/j.tox.2004.11.039]

Bailey, J.L., 2010. Factors regulating sperm capacitation. Syst. Biol. Reprod. Med., 56(5):334-348. [doi:10.3109/1939 6368.2010.512377]

Benzie, I.F.F., Strain, J.J., 1996. The Ferric reducing ability of plasma (FRAP) as a measure of "antioxidant power": the FRAP assay. Anal. Biochem., 239(1):70-76. [doi:10. 1006/abio.1996.0292]

Brand-Williams, W., Cuvelier, M.E., Berset, C., 1995. Use of a free-radical method to evaluate antioxidant activity. LWT-Food Sci. Technol., 28(1):25-30. [doi:10.1016/ S0023-6438(95)80008-5]

Fardilha, M., Esteves, S.L., Korrodi-Gregório, L., et al., 2011. Identification of the human testis protein phosphatase 1 interactome. Biochem. Pharmacol., 82(10):1403-1415. [doi:10.1016/j.bcp.2011.02.018]

Hiromoto, T., Honjo, E., Tamada, T., et al., 2013. Crystal structure of UDP-glucose: anthocyanidin 3-O-glucosyltransferase from Clitoria ternatea. J. Synchrotron Radiat., 20(6):894-898. [doi:10.1107/S0909049513020712]

Honda, T., Saito, N., 2002. Recent progress in the chemistry of polyacylated anthocyanins as flower color. Heterocycles, 56(1-2):633-692. [doi:10.3987/REV-01-SR(K)2]

Iamsaard, S., Prabsattroo, T., Sukhorum, W., et al., 2013. Anethum graveolens Linn. (dill) extract enhances the mounting frequency and level of testicular tyrosine protein phosphorylation in rats. J. Zhejiang Univ.-Sci. B. (Biomed. \& Biotechnol.), 14(3):247-252. [doi:10.1631/ jzus.B1200287]

Kinobe, R.T., Dercho, R.A., Vlahakis, J.Z., et al., 2006. Inhibition of the enzymatic activity of heme oxygenases by azole-based antifungal drugs. J. Pharmacol. Exp. Ther., 319(1):277-284. [doi:10.1124/jpet.106.102699]

Marwaha, R.K., Maheshwari, A., 1999. Systemic antifungal therapy in pediatric practice. Ind. Pediatr., 36(10): 1011-1021.

Morales, P., Díaz, E.S., Kong, M., 2007. Proteasome activity and its relationship with protein phosphorylation during capacitation and acrosome reaction in human spermatozoa. Soc. Reprod. Fertil. Suppl., 65:269-273.

Mukherjee, P.K., Kumar, V., Kumar, N.S., et al., 2008. The Ayurvedic medicine Clitoria ternatea-from traditional use to scientific assessment. J. Ethnopharmacol., 120(3): 291-301. [doi:10.1016/j.jep.2008.09.009]

Nithianantham, K., Shyamala, M., Chen, Y., et al., 2011. Hepatoprotective potential of Clitoria ternatea leaf extract against paracetamol induced damage in mice. Molecules, 16(12):10134-10145. [doi:10.3390/molecules 161210134]

Patil, A.P., Patil, V.R., 2011. Clitoria ternatea Linn.: an overview. Int. J. Pharm. Res., 3:20-23.

Pon, A., 1987. Long-term experience with high-dose ketoconazole therapy in patient with stage D2 prostatic 
carcinoma. J. Urol., 137(5):902-904.

Rodriguez, R.J., Acosta, D.Jr., 1995. Comparison of ketoconazole- and fluconazole-induced hepatotoxicity in a primary culture system of rat hepatocytes. Toxicology, 96(2):83-92. [doi:10.1016/0300-483X(94)02911-D]
Yamashita, S., Tai, P., Charron, J., et al., 2011. The Leydig cell MEK/ERK pathway is critical for maintaining a functional population of adult Leydig cells and for fertility. Mol. Endocrinol., 25(7):1211-1222. [doi:10.1210/me. 2011-0059]

\section{中文㔍要:}

本文题目：蝶豆花提取物的抗氧化活性及其对酮康唑诱导大鼠睪丸损伤的保护作用

Antioxidant activity and protective effect of Clitoria ternatea flower extract on testicular damage induced by ketoconazole in rats

研究目的：研究蝶豆花提取物的抗氧化活性及其对酮康唑（KET）诱导雄性大鼠睪丸损伤的保护作用。

创新要点: 对蝶豆花提取物保护酮康唑引起的雄性动物睪丸损伤进行研究, 为减轻抗真菌药物酮康唑的 生殖毒性提供理论依据和解决途径。

研究方法: 采用 2,2-二苯基-1-苦肼基自由基（DPPH）分析法和亚铁还原能力实验法（FRAP）来测定蝶 豆花提取物的抗氧化活性。在为期 28 天的动物试验中, 前 21 天为预防期, 第 21 至 28 天为 KET 诱导期。整个试验期中，对雄性大鼠进行蝶豆花提取物（0、50、100 mg/kg BW）灌胃 饲养; 在诱导期, 同时腹腔注射 KET (100 mg/kg BW)。试验结束后，测定睪丸、附睪和输 精管以及精囊的重量、血清睪酮水平、精子浓度、组织结构、睪丸的直径和睪丸酪氨酸磷酸 化水平。

重要结论: 蝶豆花提取物具有清除 DPPH 自由基能力和较高的还原能力, 其在 $100 \mathrm{mg} / \mathrm{kg} \mathrm{BW}$ 下对雄性 大鼠生殖系统无毒。50、100 mg/kg BW 蝶豆花提取物能改善 KET 引起的生殖器官重量下降、 血清睪酮水平和精子浓度, 降低 KET 引起的睪丸损伤。与其他组相比, $100 \mathrm{mg} / \mathrm{kg} \mathrm{BW}$ 蝶豆 花提取物能显著提高睪丸中 50-kDa 的酪氨酸磷酸化蛋白的表达。由此可见，具有抗氧化活 性的蝶豆花提取物不会损伤雄性生殖系统, 而且具有保护 KET 诱导大鼠睪丸损伤的作用。

关键词组: 蝶豆花提取物; 抗氧化活性; 酮康唑 (KET); 睪丸损伤; 酪氨酸磷酸化 